\section{Ufullstendig om førstehjelp}

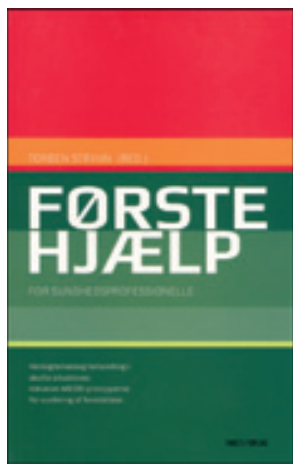

Torben Stryhn, red.

Førstehjælp for sundhedsprofessionelle

108 s, tab, ill. København: FADL's Forlag,

2011. Pris DKK 230

ISBN 978-87-7749-601-1

Lege Torben Stryhn fra Odense universitetssykehus skriver i forordet at det forventes av helsepersonell at de skal handle hensiktsmessig $\mathrm{i}$ akutte situasjoner. Med denne boken $\mathrm{i}$ hånden håper han at helsepersonell skal ha de beste forutsetninger for å handle rasjonelt og effektivt på et skadested. Målgruppen er medisinstudenter og annet helsepersonell som har pasientkontakt.

Det er 13 kapitler som alle avsluttes med enkle kasuistikker som man skal løse selv. Forfatterne henviser ikke til kilder eller annen litteratur, hvilket er en svakhet når de fremsetter påstander som at «jo høyere utdannelse førstehjelperen har (leger), jo dårligere resultat får pasientene». Boken er illustrert med svart-hvitt-bilder, tegninger i rødt, grått og svart og noen tabeller. Svart-hvitt-bildene er ikke gode, men tegningene og tabellene er illustrative og tydelige. Kapitlene varierer svært i faglig nivå. De bruker tidvis mye plass til definisjoner av latinske termer og avanserte tiltak som endotrakeal intubasjon, mens de ikke nevner brystsmerter eller tegn på akutt hjerneslag der tidsaspektet er viktig.

Enklere hjelpemidler som lommemaske og beskyttelsesduk som man alltid kan ha med seg i bilen eller på nøkkelknippet, er ikke nevnt. Jeg savner et oversiktlig flytdiagram for basal og avansert hjerte-lunge-redning. Behandlingen av fremmedlegeme i luftveiene hos barn er mangelfullt forklart.

Ved gjenopplivning forklarer forfatterne i detalj om atropin, og de anbefaler medikamenter gitt intravenøst umiddelbart før defibrillering, hvilket ikke passer med norske anbefalinger (1). For utøvelse av førstehjelp er kunnskap om immobilisering, kompresjon, eventuelt nedkjøling og elevasjon av skadet kroppsdel mer nyttig enn detaljerte frakturinndelinger. Både i ortopedikapitlene og i kapitlet om respirasjonsproblemer legger man opp til at en del skader, og pasienter med antatt psykogen årsak til hyperventilasjon, frikjennes av førstehjelperen. Dette passer ikke med det vi anser for å være en faglig forsvarlig øyeblikkelig hjelp-praksis i Norge i dag.

Førstehjcelp for sundhedsprofessionelle er etter mitt syn ikke blitt det hjelpemiddel forfatterne håpet den skulle bli. Akutte situasjoner krever kunnskap om korrekte og oppdaterte behandlingsalgoritmer, innlærte basale håndgrep og repetert trening.

Det finnes i dag gode norske lærebøker, kurs i førstehjelp og nettsider på norsk, for eksempel Norsk resuscitasjonsråds sider (2). Helsepersonell har et eget ansvar for å sørge for å holde seg faglig oppdatert, men bør etterlyse opplæring på arbeidsplassen. Argumentasjonen er enkel: Det nytter lite med avanserte og høyteknologiske tiltak ut i forløpet hvis de som kommer først til pasienten, ikke kan yte god førstehjelp.

\section{Anne-Cathrine Braarud}

Ambulanseavdelingen, Akuttklinikken

Oslo universitetssykehus

\footnotetext{
Litteratur

1. Om norske retningslinjer for hjerte-lungeredning - 2010. Norsk resuscitasjonsråd. www.nrr.org/wp-content/uploads//2010/12/1-Om-norske-retningslinjer2010.pdf (30.8.2011)

2. Norsk resuscitasjonsråd. www.nrr.org (30.8.2011)
}

\section{Psykiske vansker hos barn og unge}

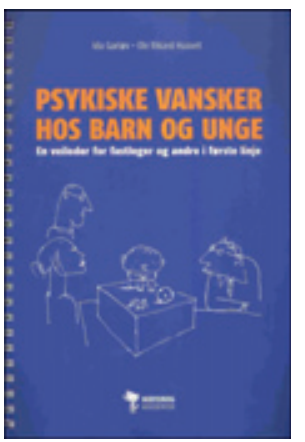

\section{Ida Garløv, Ole Richard Haavet Psykiske vansker hos barn og unge}

En veileder for fastleger og andre i første linje. 174 s, tab, ill. Stavanger: Hertervig Akademisk, 2010. Pris NOK 290

ISBN 978-82-8217-017-8

Psykiske vansker hos barn og unge er et viktig tema for primærhelsetjenesten. Denne utgivelsen er ment som et verktøy i den alminnelige kliniske hverdagen. Forfatterne er fagpersoner med betydelig erfaring på fagfeltet. Haavet er forsker og spesialist i allmennmedisin. Garløv er spesialist i barne- og ungdomspsykiatri og har i flere år arbeidet i og med primærhelsetjenesten. I tillegg er boken støttet av en rekke andre fagpersoner som er nevnt i forordet.

Førsteinntrykket er positivt og overkommelig for helsepersonell som vil oppdatere seg i løpet av få timer. Innholdet er oversiktlig og stikkordregisteret dekkende. Boken har håndbokformat og skal tilpasses Norsk elektronisk legehåndbok (NEL). Den gir god informasjon om fastlegen som samtalepartner for barn og unge, og detaljert informasjon om de vanligste diagnosene. Spørsmålet er om forfatterne ikke er for detaljerte når det gjelder diagnoser, i en bok som i stor grad har korte setninger og stikkordsform. Som oppslagsverk er den ikke omfattende nok til at man kan oppdatere seg på findiagnostikk. Omtale av undergrupper, f.eks. når det gjelder angstlidelser, har etter min vurdering gått på bekostning av annen viktig informasjon. Jeg savner f.eks. utdyping av hvordan symptomer på psykisk lidelse kan avvike mellom ungdom og voksne, og om konsekvenser i hverdagen for unge med psykiske lidelser. Det er skuffende at samhandlingskapitlet handler om henvisning til spesialisthelsetjenesten, uten å ta opp de egentlige utfordringene når det gjelder samhandling. Her savner jeg først og fremst konkret informasjon om mål og metoder for samhandling med skoler og foreldre som ser barn og unge i hverdagen. Det er også naturlig å inkludere psykiatriske ungdomsteam, oppfølgingstjenesten, pedagogisk-psykologisk tjeneste, psykiatritjenesten i kommunene etc. Når det gjelder forebygging og behandling, etterlyser jeg et kapittel om fysisk aktivitet. Her finnes godt dokumentert effekt. Med kjennskap til lokale tilbud har primærhelsetjenesten en unik mulighet til å veilede unge om trening og aktivitet. Søvnvansker som symptom på, og årsak til, psykiske vansker burde også ha vært et naturlig tema.

Boken inneholder en rekke skjemaer for vurdering av psykisk helse, men min påstand er at disse i stor grad er overflødige dersom man følger opp det forfatterne skriver om samtaler med unge innledningsvis, og samhandler med andre som har ansvar for denne aldersgruppen. Som oppslagsverk er ringpermformatet godt, med oversiktlig layout. Den mangler likevel noe på struktur. Innledningsvis i hvert kapittel er det f.eks. listet opp punkter det er viktig å kjenne til, men man finner ikke alltid svar i teksten. Det er heller ikke samsvar mellom overskriftene i alle kapitler, noen steder henvises det til litteratur, andres steder til referanser. Innholdet i litteraturlisten kan være vanskelig å velge i en kortfattet veileder. Haavet har selv flere viktige artikler om ungdom, men jeg savner andre forfattere og oversiktsartikler om psykiske vansker, behandling og samhandling.

\section{Siren Haugland \\ Uni Research \\ Bergen}

